https://doi.org/10.18778/1427-9711.13.04

Marta Wiśniewska, Jacek Forysiak

Katedra Geomorfologii i Paleogeografii

Wydział Nauk Geograficznych, Uniwersytet Łódzki

Artykuł wpłynął do redakcji 07.06.2014; po recenzjach zaakceptowany 06.12.2014

\title{
ŹRÓDŁA CIEPŁA NISKOTEMPERATUROWEGO DOSTEPNEGO DLA GRUNTOWYCH PIONOWYCH WYMIENNIKÓW CIEPŁA. UWARUNKOWANIA ŚRODOWISKOWE I TECHNICZNE
}

\section{LOW ENTHALPY HEAT SOURCES AVAILABLE FOR VERTICAL GROUND HEAT EXCHANGERS. TECHNICAL AND ENVIRONMENTAL CONSIDERATIONS}

Wykorzystanie niskotemperaturowego ciepła, zawartego w przypowierzchniowych warstwach skorupy ziemskiej jest jednym ze sposobów zagospodarowania energii geotermalnej. Pozyskiwana jest ona za pomocą gruntowych pomp ciepła (GPC). Instalowanie gruntowych pomp ciepła $\mathrm{z}$ pionowymi wymiennikami jest korzystne z punktu widzenia efektywności ekonomicznej, niewielkiego wpływu na środowisko oraz poszerzania zakresu wykorzystania odnawialnych źródeł energii. W artykule podano najważniejsze uwarunkowania środowiskowe: gradient geotermiczny, naturalny ziemski strumień ciepła, przewodność cieplną skał oraz lokalne warunki hydrogeodynamiczne. Wskazane zostały podstawowe warunki techniczne dla instalacji gruntowych pomp ciepła. Zwrócono również uwagę na znaczenie parametrów termicznych skał. W Polsce liczba zainstalowanych gruntowych pomp ciepła jest niższa w porównaniu z innymi krajami europejskimi. Jednym z problemów w zastosowaniu tych urządzeń jest niewystarczające rozpoznanie specyficznych warunków gruntowo-wodnych pod pionowe gruntowe wymienniki ciepła, co wpływa na ekonomiczną efektywność tego typu inwestycji.

Artykuł jest przeglądem publikacji poświęconych zarysowanemu problemowi.

Słowa kluczowe: geotermalne/gruntowe pompy ciepła (GPC), warunki gruntowo-wodne dla GPC, energia niskiej entalpii 


\section{Wprowadzenie}

Jednym ze sposobów wykorzystania energii geotermalnej jest eksploatacja niskotemperaturowego ciepła z przypowierzchniowych warstw skorupy ziemskiej zawartego w skałach luźnych, wodach i płytko położonych skał litych, odzyskiwanego za pomocą instalacji geotermalnych/gruntowych pomp ciepła (GPC). Gruntowe pompy ciepła są instalacjami składającymi się z pompy ciepła z gruntowym wymiennikiem ciepła (system zamknięty) lub pompy ciepła zasilanej wodami podziemnymi ze studni (system otwarty).

Skały lite, osady luźne i wody podziemne magazynują ciepło dostarczane przez energię słoneczną i energię pochodzącą $\mathrm{z}$ wnętrza Ziemi. Niewielkie wartości przewodności cieplnej skał zapobiegają szybkiemu rozproszeniu magazynowanej energii cieplnej. Przypowierzchniowe warstwy litosfery są zatem ogromnym rezerwuarem niskotemperaturowego ciepła, dostępnego dla instalacji pionowych gruntowych wymienników i pomp ciepła. Lokalnie, źródłem ciepła dla przypowierzchniowych warstw gruntu może być także działalność antropogeniczna, związana $\mathrm{z}$ procesami cieplnymi zachodzącymi w otoczeniu składowisk odpadów (fermentacja), hałd poeksploatacyjnych węgla kamiennego, sieci kanalizacyjnych czy ciepłowniczych, wód zrzutowych z elektrowni cieplnych czy działalności górniczej itp. (Kapuściński, Rodzoch, Rodzoch 2010; Śliwa, Gonet 2011). Wzrost naturalnej temperatury gruntu obserwuje się także w bezpośrednim otoczeniu fundamentów budynków.

Podłoże skalne akumuluje i przechowuje pochłoniętą energię, którą można wykorzystać za pomocą gruntowych pomp ciepła. Wymaga to jednak pełnego rozpoznania podpowierzchniowego budżetu energetycznego i oszacowania parametrów związanych z pojemnością cieplną, przepływem wody, przepuszczalnością ośrodka skalnego oraz rozkładem pola naprężeń (Gonet 2011) ${ }^{1}$.

Za główne zalety zastosowania gruntowych wymienników ciepła uważa się:

- minimalne ryzyko inwestycyjne, związane z możliwością wykorzystania ciepła z Ziemi w niemal każdych warunkach geologicznych (Rybach, Sannner 2000),

- łatwość wykonania oraz konstrukcji,

- efektywność ekonomiczną (w perspektywie czasu żywotności instalacji),

- wieloletnią niezawodność systemu,

- możliwość pracy rewersyjnej (tryb chłodzenia oraz tryb ogrzewania),

- brak negatywnego (bądź minimalne) oddziaływanie na środowisko,

- odnawialność źródła energii,

${ }^{1}$ Współcześnie coraz częściej wykorzystuje się magazynowanie ciepła w gruncie Underground Thermal Energy Storage (UTES), bądź pompy rewersyjne, umożliwiające magazynowanie ciepła odzyskowego z procesu klimatyzacji i wykorzystywanie go w sezonie grzewczym. Rozwiązania tego typu zwiększają stabilność temperaturową dolnego źródła (Kapuściński, Rodzoch, Rodzoch 2010). 
- znaczącą oszczędność energii w trybie chłodzenia (w porównaniu do tradycyjnych systemów klimatyzacji).

W ostatnich kilku latach wzrosło zainteresowanie instalacjami do uzyskiwania ciepła z gruntowych wymienników. Przy planowaniu i realizacji tych instalacji potrzebna jest znajomość lokalnych warunków gruntowo-wodnych.

Niniejsza publikacja ma charakter przeglądowy, prezentuje najważniejsze czynniki techniczne oraz środowiskowe, wpływające na koszty oraz funkcjonowanie instalacji gruntowych pomp ciepła. Artykuł oparto na bogatej literaturze, szczególnie anglojęzycznej, wybrano przykłady z Europy Zachodniej, a przede wszystkim Skandynawii, gdzie energia geotermalna eksploatowana jest już od kilkudziesięciu lat. Również w Polsce powstało wiele prac ukazujących uwarunkowania dla tego źródła energii w warunkach polskich.

\section{Uwarunkowania techniczne}

$\mathrm{W}$ instalacjach gruntowych pomp ciepła wykorzystywana jest energia geotermalna niskiej entalpii (GNE), to jest taka energia cieplna, której źródło wody podziemne lub skały mają temperaturę poniżej $20^{\circ} \mathrm{C}$ (Kapuściński, Rodzoch, Rodzoch 2010). Bezpośrednie pozyskanie przez użytkownika energii geotermalnej niskiej entalpii nie jest możliwe, niezbędne do jej wykorzystania jest zastosowanie urządzeń wspomagających tzw. geotermalnych pomp ciepła. Pomimo konieczności zastosowania urządzeń wspomagających odbiór ciepła z Ziemi, możliwość pozyskania energii cieplnej nie jest tak silnie uzależniona od specyficznych warunków geologicznych, jak w przypadku geotermii wysokiej entalpii ${ }^{2}$. Taki sposób wykorzystania energii można zastosować w niemal każdych warunkach gruntowych (Rybach, Sanner 2000; Sanner i in. 2003), ponieważ wymaga jedynie dostosowania typu systemu do lokalnych warunków gruntowo-wodnych.

Gruntowe/geotermalne pompy ciepła (GPC) stosowane są w dwóch podstawowych systemach instalacyjnych: zamkniętym i otwartym. Wśród systemów otwartych rozróżnia się wymienniki: pionowe, poziome, koszowe i palowe. Wykorzystują one ciepło gruntu i/lub wód podziemnych/powierzchniowych, a wymiana ciepła następuje za pomocą medium krążącego bez bezpośredniego kontaktu z otoczeniem. W systemie otwartym wykorzystuje się wody powierzchniowe lub podziemne (pompowane ze studni), odprowadzane do otoczenia po oddaniu ciepła. Najczęściej wykorzystanym rozwiązaniem są pionowe gruntowe wymienniki ciepła/sondy pionowe (system zamknięty). W przypadku sond

\footnotetext{
${ }^{2}$ Determinanty ograniczające zastosowanie geotermii wysokiej entalpii płyną ze specyficznych i lokalnych warunków geologicznych i hydrogeologicznych, ekonomicznych oraz ekologicznych ograniczających znacznie obszary możliwości jej wykorzystania.
} 
pionowych/otworowych pracujących w systemie zamkniętym, instalacja pobierająca ciepło (tzw. dolne źródło) najczęściej składa się z U-rurek, umieszczonych w pionowym odwiercie. Wykonane są one z polietylenu i wypełnione niezamarzającym płynem pośredniczącym, tzw. czynnikiem roboczym, który odbiera rozproszone, niskotemperaturowe ciepło gruntu i/lub wód podziemnych. Taki wymiennik otworowy może pobierać ciepło z ośrodka gruntowo-wodnego, służące do ogrzewania oraz przygotowania ciepłej wody użytkowej, jak i je oddawać (klimatyzacja, chłód technologiczny). Może służyć także do magazynowania energii (ciepła słonecznego oraz ciepła odpadowego) w gruncie, zgodnie z koncepcją UTES (Underground Thermal Energy Storage). Przepływ ciepła ze środowiska gruntowego do wymiennika odbywa się na zasadzie różnicy temperatur, a ilość energii wymienianej pomiędzy ośrodkiem gruntowo-wodnym a wymiennikiem uwarunkowana jest gradientem temperatur pomiędzy sondą a ośrodkiem skalnym oraz zastosowaną konstrukcją sondy.

\section{Uwarunkowania środowiskowe}

Głębokościowy rozkład temperatury kształtowany jest przez geologiczne źródła energii (remanentne, radiogeniczne) oraz przez zmiany temperatury związane z fluktuacjami klimatycznymi, m.in. w cyklach glacjalno-interglacjalnych (Szewczyk 2010). Strumień energii cieplnej przepływający w środowisku skalnym jest zjawiskiem złożonym, na który wpływ mają czynniki geologiczne, hydrogeologiczne i klimatyczne (Śliwa i in. 2003, 2010, 2013; Gonet 2011). Wśród czynników środowiskowych wpływających na efektywność energetyczną i koszty instalacji grzewczo/chłodzących z pionowymi wymiennikami ciepła dominują czynniki geologiczne:

- gradient geotermiczny,

- naturalny ziemski strumień ciepła,

- przewodność cieplna skał w przewiercanym profilu,

- anizotropia ośrodka skalnego,

- gęstość skał,

- ciepło właściwe skał,

- porowatość skał,

- występowanie strefy neutralnej,

oraz hydrogeologiczne i klimatyczne:

- nasycenie skał wodą,

- rodzaj nośnika (medium) wypełniającego przestrzenie skalne,

- lokalne warunki hydrogeodynamiczne,

- głębokość periodycznego wnikania ciepła do ośrodka skalnego,

- lokalne warunki klimatyczne.

Transport energii cieplnej w litosferze przebiega głównie poprzez kondukcyjne przenoszenie ciepła, opisane prawem Fouriera. W strefie aktywnej 
wymiany wód podziemnych ciepło rozchodzi się także poprzez konwekcję, zaś radiacja nie odgrywa znaczącej roli (Kjaran, Elliason 1983; Ungemach 1987). Dostarczanie ciepła następuje w wyniku propagowania wgłąb profilu energii słonecznej oraz dyfuzji ku powierzchni energii wnętrza Ziemi. W przypadku zawodnienia ośrodka skalnego na transport energii cieplnej docierającej do ośrodka skalnego, oprócz przewodzenia, wpływa także konwekcja. Temperatury litosfery w głównej mierze zależą więc od głębokości, warunków geologicznych i hydrogeologicznych.

Temperatura przypowierzchniowych warstw skorupy ziemskiej jest w pewnym stopniu determinowana średnią roczną temperaturą powietrza. W przypadku braku adwekcji przez wody podziemne, energia cieplna docierająca do powierzchni Ziemi propaguje do głębokości kilku metrów wgłąb profilu (Banks 2008). Szacuje się, że dla warunków europejskich średnia roczna ilość promieniowania przychodzącego netto waha się $\mathrm{W}$ zakresie $40-80 \mathrm{~W} / \mathrm{m}^{-2}$ (Linacre, Geerts 1997). Skały i osady posiadają wysokie wartości objętościowej pojemności cieplnej, przy niewielkich wartościach przewodności cieplnej $(\lambda)$, stąd przyjmują niskie wartości współczynnika dyfuzji cieplnej (Banks 2008).

Temperatura płytkich warstw gruntu waha się w cyklach zarówno dobowych, jak i sezonowych. Wahania dobowe temperatur zanikają na głębokości 0,8-1,0m, wahania roczne na głębokości 15-20 m (Schmuck 1966). Na głębokości około $15 \mathrm{~m}$ temperatura warstw skalnych jest relatywnie stabilna (rys. 1), będąc w przybliżeniu równa średniej rocznej temperaturze powietrza na danym obszarze (Sanner i in. 2000; Banks 2008). Do głębokości ok. 15 m p.p.t. temperatura zależy więc od promieniowania słonecznego oraz klimatycznych (sezonowych) wahań temperaturowych. W zależności od położenia obszaru, wartości te są zróżnicowane i wynoszą np. w Skandynawi 2-9 ${ }^{\circ} \mathrm{C}$, w Niemczech $9-11^{\circ} \mathrm{C}$, we Włoszech $13-17^{\circ} \mathrm{C}$ (Ochsner 2007). W Polsce, temperatura poniżej tej głębokości wynosi średnio około $9-10^{\circ} \mathrm{C}$ (rys. 1). Temperatura w gruncie w sezonie zimowym jest więc wyższa od temperatury powietrza (latem jest odwrotnie) i może być przekształcona na wyższy poziom termodynamiczny za pomocą gruntowych pomp ciepła i służyć celom grzewczym. W okresie letnim jest odwrotnie, więc różnice temperatur mogą być wykorzystane do schładzania. Poniżej strefy neutralnej temperatura ośrodka skalnego wzrasta wraz z głębokością. Uzależniona jest od budowy geologicznej oraz wgłębnej struktury skorupy ziemskiej w danym regionie.

Do pionowych wymienników umieszczonych w otworach wiertniczych o głębokości od 30-200 m energia cieplna dociera „od góry” i „od dołu”. Od góry dociera ciepło akumulowane w gruncie, którego źródłem jest energia słoneczna. Od dołu natomiast - energia geotermalna (rys. 2). Wzrost temperatury wraz z głębokością uzależniony jest od wielkości strumienia energii płynącego z wnętrza Ziemi oraz od zróżnicowania termicznych właściwości 


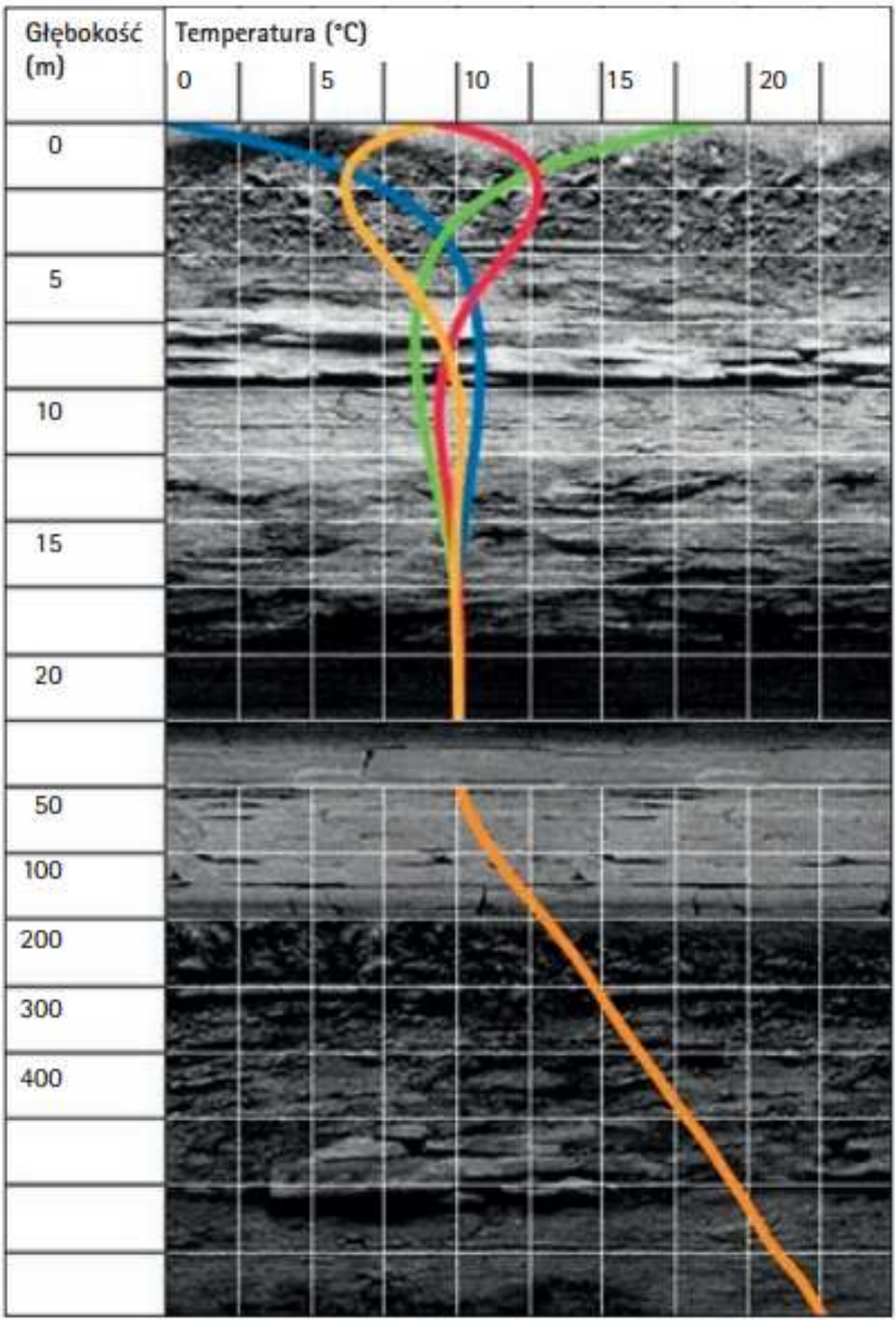

Rys. 1. Profil temperaturowy w górnych partiach podłoża skalnego Źródło: TransGeoTherm (2014)

Fig. 1. Temperature-depth profile in upper parts of the bedrock

Source: TransGeoTherm (2014) 


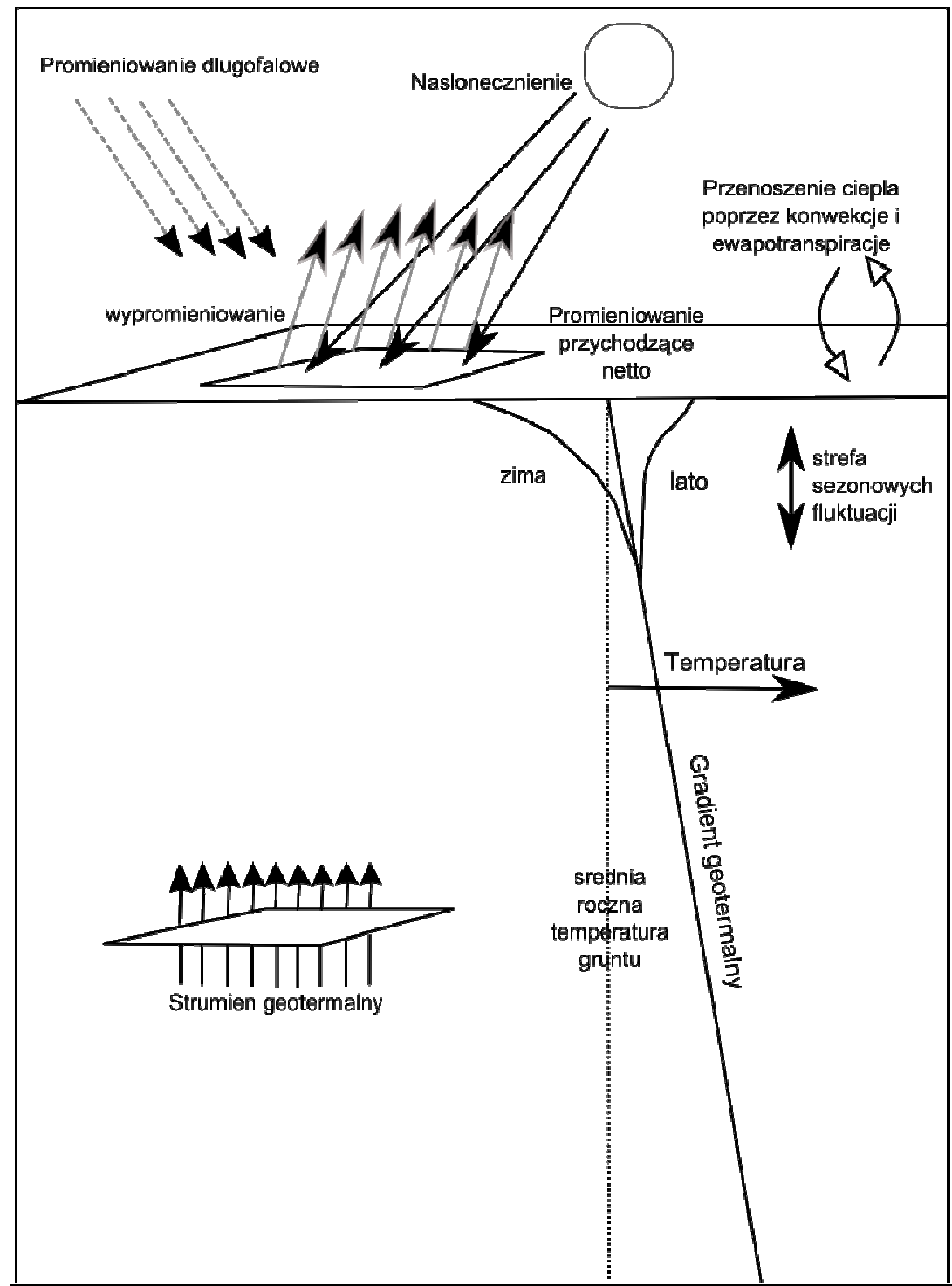

Rys. 2. Schematyczne przedstawienie wzrostu temperatury Ziemi wraz z głebokością, wywołanej gradientem geotermicznym, strefy sezonowych fluktuacji temperatury, strumienia geotermicznego i nasłonecznienia

$$
\text { Źródło: D. Banks (2008) }
$$

Fig. 2. Schematic block diagram showing the downward increase in temperature in the earth due to the geothermal gradient,the zones of fluctuation in temperature, and insolation

Source: D. Banks (2008) 
(Szewczyk 2010). Wartości stopnia i gradientu geotermicznego wykazują ścisłe zgodności ze strukturą skał i ich litologią, co wynika ze ścisłej korelacji między litologią osadów i właściwościami cieplnymi (przewodnością i opornością cieplną). Związek ten wskazuje na zależność gradientu i stopnia geotermicznego od strumienia cieplnego i własności cieplnych ośrodka skalnego (Majorowicz 1974). Wartości gradientu geotermicznego różnią się znacznie w zależności od lokalizacji $\left(2-3,5^{\circ} \mathrm{C} / 100 \mathrm{~m}\right.$ ) (Banks 2008), (średnio $3^{\circ} \mathrm{C} / 100 \mathrm{~m}$ ) (Szewczyk 2011). Intensywność dyfuzji ciepła $\mathrm{z}$ głębszych warstw skorupy ziemskiej w kierunku jej powierzchnii określa się mianem gęstości strumienia cieplnego (Sokołowski 1996).

Dla Europy charakterystyczne są niskie i średnie wartości gęstości strumienia cieplnego Ziemi, wahające się w zakresie $30-40 \mathrm{~mW} / \mathrm{m}^{2}$, na obszarze wschodnioeuropejskiej platformy prekambryjskiej (Hurter, Haenel 2002; Kępińska 2006), do $60-80 \mathrm{~mW} / \mathrm{m}^{2}$ w obrębie orogenu alpejskiego. Wartości najwyższe $150-200 \mathrm{~mW} / \mathrm{m}^{2}$ występują na Islandii (Kępińska 2006). Średnie wartości dla Europy kontynentalnej to $64 \mathrm{~mW} / \mathrm{m}^{2}$ (Banks 2008). Wartość gęstości strumienia cieplnego na Niżu Polskim wynosi średnio $40-50 \mathrm{~mW} / \mathrm{m}^{2}$ w części północno-wschodniej i centralnej, dochodząc do wartości $80-100 \mathrm{~mW} / \mathrm{m}^{2}$ w części zachodniej i południowo-zachodniej (Szewczyk, Hajto 2006). Głębokościowy rozkład temperatur jest funkcją gęstości strumienia cieplnego Ziemi $(Q)$ i wartości współczynnika przewodności cieplnej skał oraz składowej związanej z wpływem zmian klimatycznych (Clauser 1999; Szewczyk 2010). Sugeruje się, że obserwowane znaczne różnice w wartościach średnich dla półkuli północnej $\left(33 \mathrm{~mW} / \mathrm{m}^{2}\right)$ i południowej $\left(50 \mathrm{~mW} / \mathrm{m}^{2}\right)$ mogą mieć związek z czynnikiem paleoklimatycznym (Szewczyk, Hajto 2006). Lokalne zróżnicowanie temperatury ośrodka skalnego, związane ze zmiennymi wartościami strumienia cieplnego w obszarze półkuli północnej, mogło wpływać na przebieg procesów glacjalnych. Różnice w termice podłoża, wywołane strumieniem cieplnym, spowodowały zdaniem Z. Rdzanego (2011) nierównomierne rozprzestrzenianie się lądolodu warty w środkowej Polsce.

Właściwości termiczne skał zależą od szeregu czynników, wśród których najistotniejsze znaczenie ma: litologia, skład granulometryczny, gęstość i porowatość, charakter i stopień nasycenia wodą, anizotropia cieplna (związana z uwarstwieniem skał) (Rychlicki i in. 1979). Najistotniejszym parametrem wymiany ciepła między wymiennikiem gruntowym a górotworem jest przewodność cieplna skał $\left[\mathrm{Wm}^{-}{ }^{1} \mathrm{~K}^{-1}\right] \mathrm{w}$ przewiercanym profilu, określająca intensywność wymiany ciepła. Decyduje to o liczbie otworów i/lub sumarycznym metrażu zainstalowanych wymienników, w celu uzyskania oczekiwanej mocy grzewczej (Gonet 2011). Wartości, jakie przyjmuje współczynnik przewodności cieplnej uzależnione są w głównej mierze od: struktury i rodzaju minerałów budujących skałę, uziarnienia skały, jej porowatości, higroskopijności, gęstości, zwięzłości, stopnia diagenezy oraz tekstury (Chmura 1968; Gąsior, Przelaskowska 2010). Przyjmowane wartości przewodności cieplnej, która ma zasadnicze 
znaczenie, pojemność cieplna skał w przewierconym profilu oraz gęstość strumienia cieplnego na danym obszarze, są parametrami determinującymi ilość ciepła możliwego do uzyskania $\mathrm{z}$ górotworu. W praktyce pojemność cieplna odnosi się jedynie do dobowej i sezonowej zmienności mocy oraz procesów związanych z magazynowaniem ciepła w gruncie (Kapuściński, Rodzoch, Rodzoch 2010). Parametry te decydują zatem o efektywności energetycznej instalacji z gruntowymi wymiennikami ciepła. W przypadku osadów zawodnionych wartości rzeczywistej przewodności cieplnej są wypadkową przewodności szkieletu skalnego oraz wody wypełniającej pory i szczeliny w skałach. Badania wskazują bowiem, że przewodność cieplna skał nie jest zdeterminowana jedynie rodzajem osadu, lecz także jego zawodnieniem (Chmura 1968; Chiasson i in. 2000; Witte i in. 2002; Gehlin, Hellström 2003). Wzrost zawodnienia skał przekłada się bezpośrednio na wzrost wartości ich parametrów termicznych. Dla osadów zawodnionych dodatkową rolę spełnia konwekcyjne przenoszenie ciepła, uzależnione od prędkości przepływu, na którą wpływa współczynnik filtracji i spadek hydrauliczny (Rychlicki i in. 1979; Kapuściński, Rodzoch, Rodzoch 2010). Występowanie w ośrodku skalnym wód podziemnych sprzyja więc zwiększeniu efektywności pracy instalacji (wyższa temperatura płynu roboczego) ze względu na wymianę ciepła poprzez konwekcyjne przenoszenie energii cieplnej. $\mathrm{Na}$ wielkość wymiany ciepła pomiędzy wymiennikiem a górotworem wpływa ruch wód podziemnych, który może powodować zarówno szybką regenerację zasobów ciepła, jak i rozpraszanie ciepła podczas prób magazynowania energii w górotworze (Gonet 2011).

Rozpoznanie wartości przewodnictwa cieplnego skał w przewiercanym profilu geologicznym określoną współczynnikiem przewodności cieplnej skał jest niezbędnym elementem podczas wymiarowania pionowej sondy gruntowej. Dane dotyczące przewodności cieplnej skał w praktyce przyjmuje się na podstawie publikowanych wartości wyznaczonych laboratoryjnie, obliczając średnią wartość współczynnika przewodzenia na podstawie miąższości warstw i współczynników przewodzenia utworów budujących profil, jako średnią ważoną dla wszystkich gruntów w przewiercanym otworze. Rzeczywiste warunki gruntowe mogą jednak znacznie odbiegać od warunków laboratoryjnych, co może wynikać ze znacznych różnic w rodzaju gruntów, czy warunków gruntowo-wodnych w profilu wiertniczym. Różnice możliwej do uzyskania energii cieplnej z $1 \mathrm{~m}$ sondy, uzależnione od rodzaju podłoża, wahają się w dużym zakresie od $20 \mathrm{~W} / \mathrm{m}$ dla suchych osadów piaszczystych i żwirowych do $100 \mathrm{~W} / \mathrm{m}$ dla osadów piaszczystych silnie zawodnionych. W celu faktycznego rozpoznania właściwości cieplnych gruntów (analizy przewodności cieplnej osadów) in situ w danym profilu wiertniczym, przeprowadza się test TRT/GRT (Thermal Response Test/ Geothermal Response Test). 


\section{Zastosowanie gruntowych pomp ciepła w Polsce na tle trendów światowych}

Według szacunków, w 2012 r. w Polsce zainstalowanych było co najmniej 30000 geotermalnych pomp ciepła (GPC) wszystkich typów (woda/woda, woda/solanka, pętle horyzontalne, pionowe itd.). Instalacje wytwarzały $330 \mathrm{MW}_{\mathrm{t}}$ mocy i $1700 \mathrm{TJ}$ ciepła, przy czym zwraca się uwagę, że liczba ta może być większa (Kępińska 2013). Otworowe wymienniki ciepła wraz z instalacją pomp ciepła są coraz powszechniej stosowanym rozwiązaniem technologicznym umożliwiającym ogrzewanie pomieszczeń i ciepłej wody użytkowej, a także klimatyzacji, za pomocą jednego zintegrowanego urządzenia. Na wzrost zainteresowania instalacjami z pompami ciepła wpływ mają zarówno ceny paliw kopalnych, jak i rosnąca świadomość w zakresie konieczności ochrony środowiska.

Na świecie i w wielu europejskich krajach obserwuje się trend na zrównoważone gospodarowanie zasobami, w które wpisują się kwestie ogrzewania (chłodzenia) za pomocą pomp ciepła wszystkich typów. Ważny jest przy tym brak emisji substancji szkodliwych. Coraz szersze zastosowanie technologii gruntowych wymienników ciepła (GWC) związane jest z postępem technologicznym w dziedzinie ich konstrukcji oraz wykorzystywanych materiałów, a także wzrostem wiedzy z zakresu przewodności cieplnej gruntu oraz oporów otworowych wymienników ciepła, jak też coraz powszechniej stosowanym badaniom testu reakcji termicznej (TRT).

\section{Podsumowanie}

Projektowanie niezawodnych, wydajnych i trwałych systemów wymaga rozumienia właściwości termofizycznych gruntów, w których wykonuje się otwory oraz rozumienia budżetu energetycznego w środowisku gruntowo-wodnym. Niezwykle istotną częścią systemu grzewczego opartego o gruntowe pompy ciepła są cechy litologiczne tego źródła ciepła, ponieważ z niego pobierana jest energia cieplna dla całej instalacji.

Rozpoznanie specyficznych warunków gruntowo-wodnych pod pionowe gruntowe wymienniki ciepła w planowanym miejscu inwestycji, oprócz dopasowania właściwego typu systemu, pozwala uniknąć potencjalnych błędów instalacyjnych, związanych ze złym wymiarowaniem sondy. Ma to wpływ na zminimalizowanie kosztów instalacyjnych i zmaksymalizowanie wydajności pracy systemu. Podczas prac wiertniczych można natrafić na formacje skalne o skrajnie różnych właściwościach termicznych i wodnych. Szacowanie lokalnych warunków gruntowo-wodnych wykonane jedynie na podstawie danych literaturowych lub danych pochodzących z najbliżej zlokalizowanych profili 
wiertniczych, bez przeprowadzenia badań in situ, prowadzi do ich nierozpoznania bądź do ich nieprawidłowego określenia. W konsekwencji może to doprowadzić do błędów instalacyjnych, zainicjowanych już na etapie planowania. Mogą one utrudniać prace wiertnicze i powodować problemy w późniejszej eksploatacji sytemu, takie jak np. wychłodzenie gruntu na skutek poboru większej ilości energii niż tej przychodzącej, która regeneruje dolne źródło. Najczęstsze błędy przejawiają się niedoszacowaniem długości wymiennika, prowadzącym do zbyt małych mocy poborów, wówczas system nie wystarcza do zapewnienia oczekiwanej temperatury. $Z$ kolei ich przeszacowanie wpływa na wzrost kosztów instalacyjnych oraz wydłuża czas amortyzacji kosztów. Kluczem do prawidłowego wymiarowania sondy jest więc znajomość lokalnej specyfiki warunków gruntowo-wodnych.

Energia geotermalna niskiej entalpii, która jest wykorzystywana w instalacjach gruntowych pomp ciepła stanowi jedno z wielu odnawialnych źródeł energii stanowiących uzupełnienie dla źródeł konwencjonalnych. Efektywne jej wykorzystanie jest uzależnione od wielu czynników środowiskowych, technicznych i eksploatacyjnych. Wśród uwarunkowań środowiskowych najważniejsze są czynniki geologiczne, hydrogeologiczne i klimatyczne. Decydują one o ilości energii cieplnej zakumulowanej $\mathrm{w}$ wierzchnich warstwach skorupy ziemskiej. Czynniki techniczne decydują o ilości potencjalnego uzysku energii, mocy grzewczej, sposobie pozyskania i przekazania energii cieplnej do odbiorcy w sposób zapewniający efektywne jej wykorzystanie. Znajomość uwarunkowań środowiskowych i zastosowanie właściwych procedur technicznych decyduje o efektywności ekonomicznej wykorzystania energii niskiej entalpii. Polska, jak i wiele krajów europejskich, ma znaczące, potencjalne źródła tego rodzaju energii, a jej wykorzystywanie jest rozwijającą się gałęzią produkcji „czystej” energii cieplnej.

\section{LITERATURA}

Banks D., 2008, An introduction to thermogeology, ground sources heating and cooling, Blackwell, Oxford, UK. s. 1-296.

Chiasson A.,. Ress S.J., Spitler J.D., 2000, A preliminary assessment of the effects of ground-wate flow on closed-loop ground-source heat pump system, ASHRAE Transaction, $160 \mathrm{~s}$.

Chmura K., 1968, Przewodność cieplna skat i węgli górnoślaskiego karbonu, „Górnictwo", 26, Politechnika Śląska, Zeszyt Naukowy, 190, Gliwice, s. 3-127.

Clauser C., 1999, Thermal signatures of heat transfer processes in the Earth's crust, Springer, Berlin, $111 \mathrm{~s}$.

Gąsior I., Przelaskowska A., 2010, Charakterystyka parametrów termicznych skat mezopaleozoicznych z rejonu Kraków-Dębica, „Nafta-Gaz”, 56, s. 663-667.

Gehlin S., Hellström G., 2003, Comparison of four models for thermal response test evaluation,. ASHRAE Transactions, 109. s. 1-12. 
Gonet A. (red.), 2011, Metodyka identyfikacji potencjału cieplnego górotworu wraz z technologia wykonywania i eksploatacji otworowych wymienników ciepta, Wydawnictwo AGH, Kraków, 439 s.

Górecki W. (red.), 2006, Atlas zasobów geotermalnych formacji mezozoicznej na Niżu Polskim, Ministerstwo Środowiska, NFOŚiGW, AGH, PIG, Kraków.

Hurter S., Haenel R. (red.), 2002, Atlas of geothermal resources in Europe, Office for the Official Publications of the European Communities, Luxemburg.

Kapuściński J., Rodzoch J., Rodzoch A., 2010, Geotermia niskotemperaturowa w Polsce i na świecie, Borgis, Warszawa, s. 59-102.

Kępińska B., 2006, Energia geotermalna - wykorzystanie na swiecie $i$ w Europie, „Polityka Energetyczna", 9, Zeszyt specjalny, s. 545-555.

Kępińska B., 2013, Stan wykorzystania energii geotermalnej w Europie, Technika Poszukiwań Geologicznych. Geotermia, Zrównoważony Rozwój, 2, s. 5-23.

Kjaran S.P., Elliason J, 1983, Geothermal reservoir enginnering, Lecture Notes, UNU Geothermal Training Programme.

Linacre E., Geerts B., 1997, Climates and weather explained, Routledge, London, $432 \mathrm{~s}$.

Majorowicz J., 1974, Obraz pola cieplnego Ziemi w obszarze Polski, ,Rocznik Polskiego Towarzystwa Geologicznego", 44(2-3), s. 425-443.

Ochsner K., 2007, Geothermal heat pumps. A guide to planning and installing, Earthscan London, Sterling, s. 11-69.

Rdzany Z., 2011, Wptyw energii geotermalnej na dynamike strumieni lodowych ladolodu warty w Polsce środkowej, [w:] Zieliński A. (red.), Znane fakty - nowe interpretacje $w$ geologii $i$ geomorfologii, Instytut Geografii UJK w Kielcach, s. 49-63. DOI: $11089 / 1146$

Rybach L., Sanner B., 2000, Ground-source heat pump systems; the European experience, „Geo-Heat Center Bulletin”, 21(1), s. 16-26.

Rychlicki S., Twardowski K., Trafle J., Krochmal J., 1979, Wybrane materiaty do ćwiczeń laboratoryjnych z inżynierii złożowej i geofizyki wiertniczej, Skrypty uczelniane $\mathrm{Nr}$ 686, Akademia Górniczo-Hutnicza im. S. Staszica w Krakowie, s. 6-98.

Sanner B., Reuss M., Mands E., Müller J., 2000, Thermal Response Test-Experiences in Germany, Proceedings Terrastock, s. 177-182.

Sanner B., Karytsas C., Mendrinos, Rybach L., 2003, Current status of ground source heat pumps and underground thermal energy storage in Europe, „Geothermics”, 32, s. $579-588$.

Schmuck A., 1966, Zarys hydrometeorologii, PWN, $160 \mathrm{~s}$.

Śliwa T., Kotyza J., 2003, Application of existing wells as ground heat source for heat pumps in Poland, „Applied Energy”, 74(1-2), s. 3-8.

Śliwa T., Gonet A., 2010, Analysis of Borehole Heat Exchangers Design in View of Stream of Heat Exchange Maximization with the Rock Mass, Proceedings World Geothermal Congress, Bali, Indonesia, 25-29 April 2010, s. 1-7.

Śliwa T., Gonet A., 2011, Analiza efektywności wymiany ciepła $w$ wymiennikach otworowych różnej konstrukcji, „Wiertnictwo Nafta Gaz”, 28(3), s. 555-570.

Śliwa T., Rosen M.A., 2013, Heat Transfer Effectiveness of Borehole Heat Exchangers for Various Grouts: Analysis based on Numerically Simulated Thermal Response Tests, EIC Climate Change Technology Conference, CCTC 2013, s. 1-12.

Sokołowski J., 1996, Polska Szkoła geotermalna - zasady projektowania zakładów geotermalnych, PAN CPPGSMiE, PGA. 
Szewczyk J., Hajto M., 2006, Strumień cieplny a temperatury wgłębne na obszarze Niżu Polskiego, [w:] Górecki W. (red.), Atlas zasobów geotermalnych formacji mezozoicznej na Niżu Polskim, Wydawnictwo Ministerstwa Środowiska, NFOŚiGW, AGH, PIG, Kraków, s. 143-146.

Szewczyk J., 2010, Geofizyczne oraz hydrogeologiczne warunki pozyskiwania energii geotermicznej w Polsce, ,Przegląd Geologiczny”, 58(7), s. 566-573.

Szewczyk J., 2011, Im głębiej, tym cieplej, Państwowy Instytut Geologiczny, Zakład Hydrogeologii i Geologii Inżynierskiej, www.pig.gov.pl.

TransGeoTherm 2014, Projekt realizowany przez Państwowy Instytut Geologiczny Państwowy Instytut Badawczy - Oddział Dolnośląski (PIG-PIB OD) oraz saksońską służbę geologiczną - Sächsisches Landesamt für Umwelt, Landwirtschaft und Geologie (LfULG), s. 3-30.

Ungemach P., 1987, Reservoir Engineering Assessment of Low Enthalpy Geothermal Field Paris Basin, [w:] Okandan E. (red.), Geothermal Reservoir Engineering, Kluwer Academic Publishing, 332, s. 1-27

Witte H.J.L., van Gelder G., Spitler J.D., 2002, In-Situ Thermal Conductivity Testing: A Dutch Perspective, ASHRAE Transactions, 108(1), s. 1-21.

\section{SUMMARY}

Utilization of low enthalpy heat from the subsurface parts of the earth is one of the way of geothermal energy management. Heat pumps offer the possibility to obtain low enthalpy heat. Geothermal heat pumps (GHP) with vertical ground heat exchangers are beneficial because of the economical efficiency and small impact on the environment. Moreover they are one of the renewable energy sources. The article presents the most important environmental determinants: geothermal gradient, natural terrestrial heat flow, thermal conductivity of rocks and local hydrogeodynamic conditions. This paper also indicates the basic technical conditions for installation of ground source heat pumps and pays attention to the thermal properties of rocks. The status of GHP in Poland is lower compared to other European countries. One of the problems is insufficient recognition of the specific ground-water conditions for vertical ground heat exchangers which affects the economical efficiency of GHP installation

Keywords: geothermal heat pumps (GHP), ground-water conditions for GHP, low enthalpy energy 